\title{
Supply Chain Process Benchmarking Using a Self-Assessment Maturity Grid
}

\author{
Sander de Leeuw \\ VU University Amsterdam \\ The Netherlands
}

\section{Introduction}

Competitive advantage is more and more determined by the ability to respond to customer requirements. Research has shown that a well-organised supply chain that can meet these requirements is crucial to firm performance (2006; Ramdas \& Spekman 2000; Spekman et al. 1998). Top performance in supply chain management will result into success at the organisational level (Green Jr et al. 2008). More than ever it is important to know what drives performance in a supply chain. As a result, many companies have reverted to benchmarking their supply chain activities. Benchmarking can be defined as a search for industry best practices that lead to superior performance (Camp 1989). Looking outwards to other companies enables companies to " learn from others and achieve quantum leaps in performance that otherwise could take years to achieve through internal incremental achievements" (Van Landeghem \& Persoons 2001: 254). Such quantum leaps are often necessary to stay ahead of competition. Benchmarking is therefore more and more of strategic importance.

Benchmarking often consists of comparing performance outcomes with the outside world and the difference between the figures is considered the gap to close in the near future. However, comparing just figures bears certain dangers. Traditional approaches such as benchmarking lagging measures may be unreliable in rapidly changing business environments (Bourne et al. 2000). Furthermore, benchmarking first requires an understanding of processes benchmarked (Voss et al. 1994) and that is often not the case in traditional benchmarking approaches. Well functioning processes are a strategic asset for a company (Hammer 1990): they are crucial to achieving high performance levels and thus to achieve lasting competitive advantage. However, process benchmarking research, which focuses on finding and comparing process practices, largely remains descriptive with a focus on describing practices that successful companies have in place (Davies \& Kochhar 2002). They provide companies with limited guidance in target setting as well as developing a roadmap how to get to these targets. In this paper we focus on benchmarking processes through maturity models and we develop a maturity model that can be used as a standard to compare processes across companies, set targets and define growth paths. Recent literature identified a need to develop such models that can be used as a standard to compare different companies within a branch (Lockamy III et al. 2008).

The concept of process maturity proposes that a process has a lifecycle that is assessed by the extent to which the process is explicitly defined, managed, measured and controlled 
(Lockamy III \& McCormack 2004a; Paulk et al. 1993). Process maturity can be defined as: "the degree to which a process/activity is institutionalized and effective" (Moultrie et al. 2006). For an overview we refer to Plomp and Batenburg (2010) who recently provided an overview of 22 published maturity models. Process maturity assessment has emerged as an effective way of capturing "good practices" knowledge on processes in a form that also supports improvement initiatives. According to Moultrie et al. (2006) maturity assessments help to predict an organisation's ability to meet its goals. They also provide guidance on targeting improvement by describing the progression of performance through incremental stages of development.

Process maturity assessment originates from the field of quality management to support quality improvement. Crosby (1979)) developed a so-called maturity grid that describe stages of progression in quality management processes, positing that organisations follow an evolutionary path in adopting quality management practices. Such a grid essentially describes typical stages of behaviour at different maturity levels for each activity or sub-process in scope. The grid thus codifies what can be regarded as good as well as bad practice along with a number of intermediate stages for each activity or sub-process in scope (Moultrie et al. 2006) and can thus be used for self-assessment purposes. An advantage of such an approach is that it enables companies to easily identify the current maturity stage for each activity (i.e., the description that fits the current situation best) and to develop target maturity levels and growth paths to reach targeted maturity levels. Typically, 4 to 5 intermediate stages are described. As such, a maturity grid provides a standardised way of analysing companies.

The use of these grids in quality management initiated the use of self-assessment maturity grids in several other disciplines, with well known examples in software development (Harter et al. 2000), project management (Ibbs \& Kwak 2000; Kwak \& Ibbs 2002) and product development (Fraser et al. 2002). Although supply chain process maturity has received an increased attention over the last few years, to date process maturity research in supply chain management has mainly focused on identifying the degree of presence of best practices using a five-point Likert scale, typically from 1 (e.g. "does not exist") to 5 ("always exists"). Using this approach, Lockamy and McCormack (2004b) investigate the use of SCOR based practices and identify clusters of practices that correlate with supply chain performance . McCormack et al (2008) further extend this model to investigate the Brazilian manufacturing industry. Lockamy et al. (2008) use a similar model with five maturity variables: process structure, documentation, jobs, measures and values/beliefs. In fact, this approach describes the extent to which a certain good practice is used by a company and derives maturity from the extent to which a practice is used. A maturity grid identifies intermediate stages towards a good practice or every single activity or sub-process in scope. As a result, identification of the current practice is easier but it also provides for the ability to show a company what a growth path could look like in order to reach a desired practice. To our knowledge, none of the existing supply chain maturity models is based on such a self-assessment maturity grid that also codifies intermediate stages. In our study we therefore set out to develop a selfassessment maturity grid for supply chain processes. We tested and applied it a among companies in the business-to-business segment that typically deliver a large variety of products from stock, such as wholesalers. We analysed the results of an application of the self-assessment grid in 57 such companies to identify how maturity of supply chain processes impacts supply chain performance. Using these results we show how our maturity model correlates with supply chain performance as there is a need for “...maturity models and roadmaps, which are proven to have direct correlation with performance" (Akyuz \& Erkan 2009: 12). 
In the remainder of this chapter, we elaborate on our research design and consecutively discuss the development of a self-assessment supply chain maturity grid. We then analyse and discuss results of the empirical application of this maturity grid. We provide conclusions and recommendations for further research in the last section.

\section{Research design}

We have focused our research on non-manufacturing processes due to a relatively large focus of prior research on best practices in manufacturing processes (cf. Whybark and Vastag (1993); Voss et al. (1994); Ungan (2005); Laugen et al. (2005); Swink et al. (2005) for best practice research results in manufacturing processes). We followed the guidelines of Voss et al. (1994) in setting up a self-assessment tool. They identified that the development of such a tool requires identification of best practices (Voss et al. 1994). A team of two supply chain consultants together with the author developed a maturity grid. We first used literature to identify non-manufacturing related process categories that impact supply chain performance. This resulted in 7 categories, depicted in Fig. 1 and described in section 3.

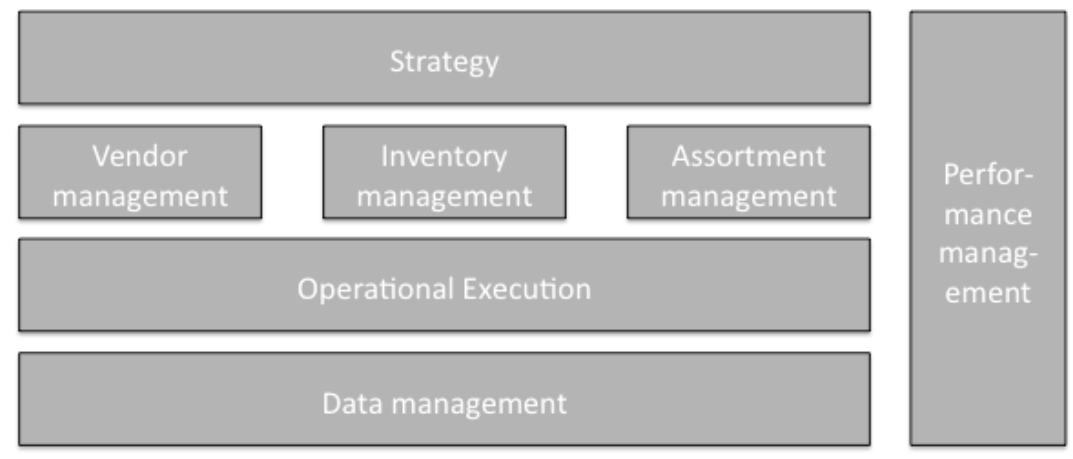

Fig. 1. Supply chain maturity processes.

We then assembled a first draft of process best practices based on a literature review and on consulting experiences within the team. Since a maturity model assumes that progress towards goal achievement comes in stages we also developed intermediate stages towards a best practice. We use five stages of maturity compared to the four that for example Voss et al. (1994) used, ranging from stage 1 "innocent", identifying lack of attention to an activity, to stage 5 "excellent" which identifies best in class. These phases can be compared to onionskins: stage five ("excellent") covers stage 4, stage 4 covers stage 3 etc. We furthermore included questions general company characteristics such as company size, assortment size, inventory levels and average order fill rate. After several iterations within the team, we tested the tool in practice. It is particularly important to test tools developed to improve content validity (Voss et al. 1994). The test took place in two phases: during the first phase, two professors who were also highly experienced supply chain consultants provided input on the maturity grid. Their additions were used for an updated model that was thereafter tested in two companies (phase two). Two companies that were considered best in class volunteered to use the model in a self-assessment: a medium-sized supplier of the offshore industry with a global distribution network and a large wholesaler in building materials with a European focus. It was decided to use two different companies as it typically is 
advisable to use rather extreme types if limited situations can be studied (Eisenhardt 1989). This resulted in the final version, which has been administered in a survey to identify where and how supply chain maturity influences supply chain performance. We used a descriptive survey as this is a useful method to increase understanding of a phenomenon and understand its distribution in a population (Forza 2002). In the next section we formulate the contents of the maturity grid.

\section{Self assessment supply chain maturity grid}

We set out to develop a maturity grid that captures the process from ordering at a supplier to actual delivery at customer premises, from strategy to execution. In contrast to other supply chain maturity research, we did not use the SCOR model directly as we focus on non-manufacturing processes and SCOR has been conceived from a manufacturing perspective (Stewart 1997). Besides, literature showed that a broader scope of processes influences supply chain performance. We have focused on seven key process categories that according to literature affect supply chain performance (see Fig. 1) ${ }^{1}$. We developed a maturity grid using the results from existing maturity models such as developed by Lockamy and McCormack (2004a) and McCormack et al. (2008). The first process in the maturity grid is "Strategy". It has been shown that a link between strategy and operations is advantageous (Bendoly et al. 2007; Braam \& Nijssen 2004; Swink et al. 2005). Lockamy and McCormack (2004a) found that more mature organisations are more effective in linking strategy to supply chain management. However, the challenge is how to achieve such strategic fit and that is not well understood (Melnyk et al. 2004). Using a self-assessment maturity grid may increase understanding of how to achieve such a fit. We furthermore included "Vendor Management", "Inventory Management" and "Assortment Management". Previous research by Ramdas and Spekman (2000) showed that highperforming companies used supplier evaluations more widely than low-performing companies. The management of vendors is more and more crucial to supply chain performance and more orientation on suppliers is generally considered to be positively related to performance (Shin et al. 2000). Van Ryzin and Mahajan (1999) conclude that assortments size has an impact on supply chain benefits. A large assortment leads to more satisfied customers but increases demand variability for each product variant due to increase product proliferation. Hendricks \& Singhal (2008) show that excess inventory levels of companies can lead to strong negative market reactions; maturity in inventory management is therefore expected to be critical. We furthermore included processes focused on "Operational Execution" and "Data Management". Operational execution relates to the actual practices in the supply chain in operationally managing demand and supply and data management to maintaining up-to-date information and full data integrity needed to perform these processes. According to Lambert \& Cooper (2000: 78) “...the kind of information and the frequency of information updating has a strong influence on the efficiency of the supply chain". Inefficient information systems, due to e.g. inaccuracies in data, are considered a key pitfall in supply chain management (Lee \& Billington 1992). The effective use of information systems is essential to efficient and speedy business operations (Tummala et al. 2006). Last, we included "Performance Management" as the adequate measurement and management of performance is a key enabler for improvement (Bourne et al. 2002; Neely et al. 2000) and critical for high performance levels (Ramdas \& Spekman

${ }^{1}$ The complete grid is available through www.supplychainmaturity.nl 
2000). In the next section, we detail the results of an analysis of maturity grids filled out by companies.

\section{Grid application and results}

The maturity grid has been developed in the Dutch language and encompasses 54 items in the 7 process categories and an additional 10 general company characteristics. To shorten total data capture throughput time and to reduce misinterpretation in filling out the grid it has been decided to collect information from companies during a executive summer course for supply chain managers from distributors and manufacturers performing their own distribution function towards retailers. This is a particularly interesting audience due to a lack of attention in supply chain management research to distributive trade (Sharman 2003). Our sampling method is similar to Zirger and Maidique (1990) who performed an empirical test on product development among participants of an executive management course. We incorporated the self-assessment maturity grid in the summary that was published for the participants of the summer school (cf. Van Dijk et al. 2007). We handed out the maturity grid on the first day of the course and had a block of 1 hour reserved in the programme on the last day to handle questions. This not only enabled a verbal explanation of the grid as well as answering any questions that may arise about the content - which increases reliability of the data - but this also provided data in a very short time. It furthermore provided the opportunity to discuss the usefulness of the grid to companies in self-assessment benchmarking.

Such convenience samples are not uncommon (cf. Zirger \& Maidique 1990) and may provide useful data with relatively limited effort compared to an extensive survey. In consumer research three criteria are used to judge whether convenience samples are applicable (Ferber 1977), which we translated for use in our situation. First, we ensured that the relevance of the sample was as targeted. The maturity grid is aimed at supply chain managers of companies delivering a relatively large assortment from stock to retailers, which was exactly the audience of the course. Secondly, the sample size must be adequate; all 57 companies completely filled out the maturity grid which is not very large but it is acceptable for such a study (Hair et al. 2006) and comparable in size to earlier research in supply chain maturity (Lockamy III \& McCormack 2004b). Third, the subjects studied should be representative of the population studied, which are stockholding companies. The 57 companies present were mainly wholesalers (49) and a few manufacturers (8). We checked for equality of variance and mean between these two groups and concluded that there were no statistical differences between these two groups. We tested discriminant validity by checking bivariate correlations between process maturity and potentially confounding variables such as company size and company turnover. We did not find significant correlations.

We used the data of the 57 maturity grids that have been filled out to identify where process maturity is key in achieving high levels of supply chain performance. The resulting Cronbach alpha was .942, which is above the minimum acceptable criterion of .7 (Hair et al. 2006). The Kaiser-Meyer-Olin measure verified sample adequacy with KMO values for the categories $>.62$, which is above the acceptable limit of .5 (Kaiser 1974). We first applied factor analysis to examine patterns underlying our data and to investigate the extent to which our information can be condensed. This revealed the critical elements of the supply chain processes. The new composite dimensions were then used to develop a regression model. Each regression model contains one independent variable and therefore these models are equal to bi-variate correlations. 
For our factor analysis, we conducted a principal component analysis on each of the seven categories of questionnaire items with orthogonal rotation (varimax). With our sample size of $\mathrm{N}=57$, we used a factor loading threshold of 0.7 (Hair et al. 2006: 128-9). The results are depicted in Table 1.

\begin{tabular}{|c|c|c|}
\hline Factor & Item & $\begin{array}{c}\text { Factor } \\
\text { loading }\end{array}$ \\
\hline \multirow[t]{2}{*}{ Strategy } & $\begin{array}{l}\text { Degree to which a company is able to define and } \\
\text { implement strategy }\end{array}$ & 746 \\
\hline & $\begin{array}{l}\text { Presence of relation between strategy on the one hand } \\
\text { and assortment, vendor and stock management on the } \\
\text { other }\end{array}$ & ,720 \\
\hline \multirow[t]{3}{*}{$\begin{array}{l}\text { Assortment } \\
\text { management }\end{array}$} & $\begin{array}{l}\text { The extent to which product introductions are } \\
\text { managed }\end{array}$ & 787 \\
\hline & $\begin{array}{l}\text { Degree of joint promotions and promotion planning } \\
\text { with partners }\end{array}$ & 747 \\
\hline & Extent of product introduction monitoring & ,730 \\
\hline $\begin{array}{l}\text { Stock management } \\
\text { factor } 1 \text { : risk analysis }\end{array}$ & $\begin{array}{l}\text { The extent to which supply chain risks are understood } \\
\text { and analysed }\end{array}$ & 857 \\
\hline \multirow{2}{*}{$\begin{array}{l}\text { Stock management } \\
\text { factor 2: organisation }\end{array}$} & The level of coordination of stock over multiple sites & 839 \\
\hline & $\begin{array}{l}\text { The extent to which stock responsibility is defined } \\
\text { clearly }\end{array}$ & 721 \\
\hline \multirow[t]{2}{*}{$\begin{array}{l}\text { Vendor management } \\
\text { factor 1: vendor analysis }\end{array}$} & $\begin{array}{l}\text { The depth and extent of measuring and managing } \\
\text { vendor performance }\end{array}$ & 824 \\
\hline & The extent of analysing and managing risks in supply & 813 \\
\hline \multirow{2}{*}{$\begin{array}{l}\text { Vendor management } \\
\text { factor } 2 \text { : Vendor } \\
\text { cooperation }\end{array}$} & Cooperative supply chain relations with vendors & 869 \\
\hline & $\begin{array}{l}\text { Level of forecast and sales information exchange with } \\
\text { suppliers }\end{array}$ & 766 \\
\hline $\begin{array}{l}\text { Operational execution } \\
\text { factor 1: up to date } \\
\text { information }\end{array}$ & $\begin{array}{l}\text { The extent to which forecasts are updated in a } \\
\text { structured fashion }\end{array}$ & 756 \\
\hline $\begin{array}{l}\text { Operational execution } \\
\text { factor 2: customer } \\
\text { cooperation }\end{array}$ & $\begin{array}{l}\text { The level of joint replenishment planning with } \\
\text { customers }\end{array}$ & 777 \\
\hline \multirow[t]{3}{*}{ Data management } & Level of standardisation in updating product data & ,746 \\
\hline & Level of mutual data transparency between partners & ,734 \\
\hline & Master data accuracy & ,728 \\
\hline \multirow[t]{5}{*}{$\begin{array}{l}\text { Performance } \\
\text { management }\end{array}$} & $\begin{array}{l}\text { Extent of internal and external communication about } \\
\text { Key Performance Indicators }\end{array}$ & 803 \\
\hline & $\begin{array}{l}\text { Extent to which performance measurement leads to } \\
\text { performance improvement initiatives }\end{array}$ & 761 \\
\hline & Content diversity of performance metrics & ,760 \\
\hline & Extent to which it is attempted to learn from others & ,748 \\
\hline & $\begin{array}{l}\text { Extent to which performance metrics are related to } \\
\text { higher-level goals }\end{array}$ & ,745 \\
\hline
\end{tabular}

Table 1. Factor analysis results 
Our factor analysis on the variables related to Strategy showed two items representing critical elements of the strategy process: first, the degree to which a company is able to define and implement strategy; second, the presence of a relation between strategy and assortment, vendor and stock management. Factor analysis further revealed three items for Assortment Management: the extent to which product introduction are managed; the degree of joint promotions and promotion planning with partners, and the extent of product introduction monitoring.

We found two relevant factors in Stock Management. The first is focused on risk analysis and contains one item: the extent to which supply chain risks are understood and analysed. The second factor relates to organisational issues of managing stock and consists of two items: the level of coordination of stock over multiple sites and the extent to which stock responsibility is defined clearly.

In the category Vendor Management, two factors were found. The first relates to vendor analysis and contains the items "depth and extent of measuring and managing vendor performance" and "extent of analysing and managing risks in supply". The second Vendor Management factor deals with vendor cooperation and consists of two items as well: the cooperative supply chain relations with vendors and the level of forecast and sales information exchange with suppliers.

Operational Execution is split into two factors each consisting of one item. The first factor is "up to date information" and this consists of the extent to which forecasts are updated in a structured fashion. The second factor, dubbed "customer cooperation", consists of the level of joint replenishment planning with customers.

Data Management consists of one factor with three items: the level of standardisation in updating product data; the level of mutual data transparency between partners, and master data accuracy. In Performance Management, five items make up one factor: the extent of internal and external communication about key performance indicators; the extent to which performance measurement leads to performance improvement initiatives; the content diversity of performance metrics; the extent to which it is attempted to learn from others and the extent to which performance metrics are related to higher-level goals.

In the next step, we used single variable linear regression analysis to identify relationships between factors and performance levels indicated in the questionnaire. In order to select which performance variables to use we first developed a correlation table (see Table 2 on the next page).

We have selected the "order fill rate" to focus our analysis on correlates as this showed the strongest correlations with the maturity factors as well as the overall mean maturity score across all grid items. We developed a regression model for on the one hand each of the maturity factors as well as the overall mean score, and on the other the performance indicator "order fill rate". The results of this regression are depicted in Table 3.

\section{Discussion}

Our research corroborates earlier results of Lockamy and McCormack (2004b, 2004a) and McCormack et al. (2008) that higher levels of maturity are correlated with higher levels of performance. When examining the impact of maturity on the individual factors on performance levels, the factor Performance Management had the highest correlation with performance of all factors. This suggests that maturity in Performance Management has a stronger impact on actual performance levels than the other processes. This finding details earlier research that performance management not only has a positive effect of measuring 


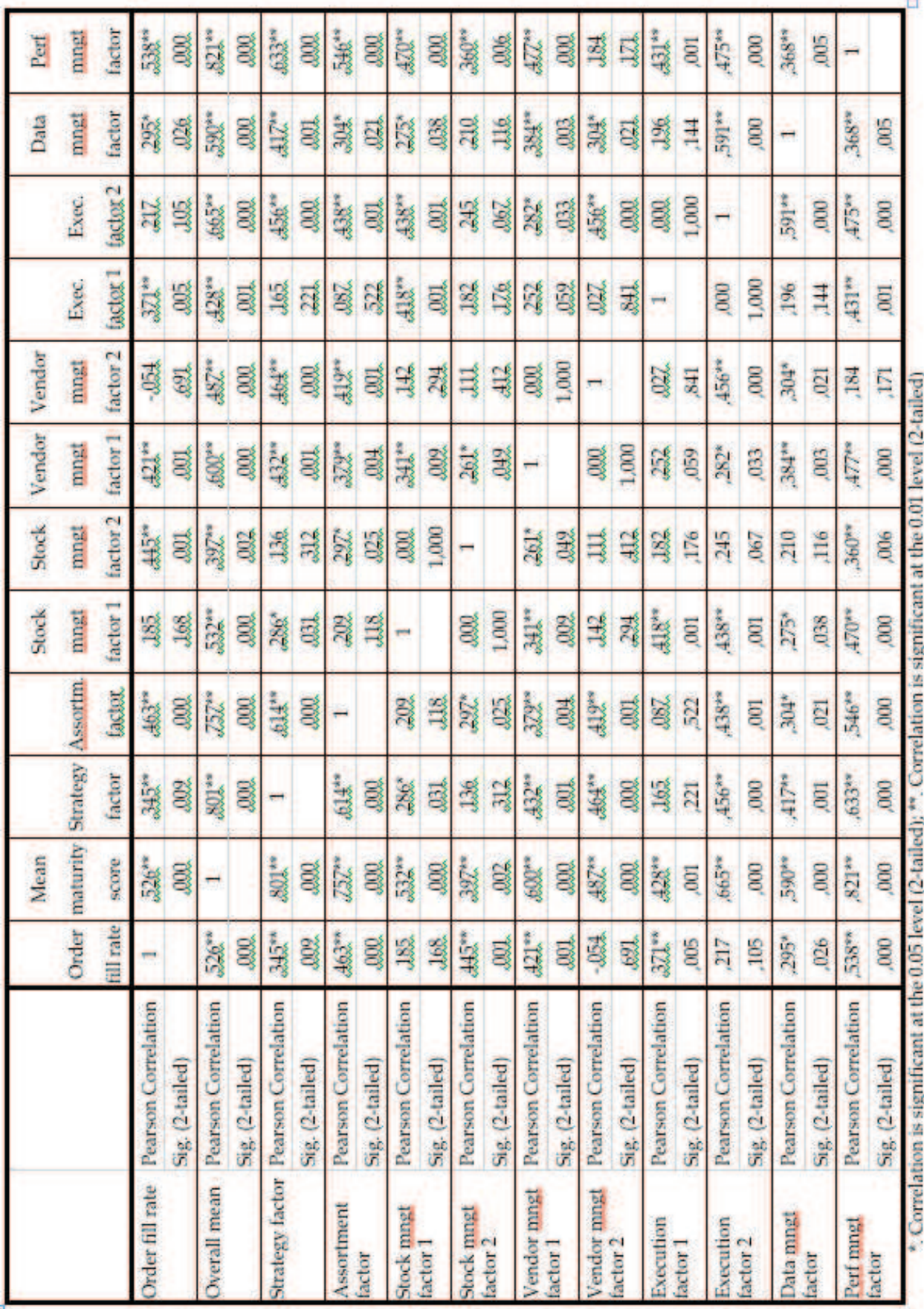

Table 2. Correlation analysis 


\begin{tabular}{|l|l|l|l|}
\hline Factor & Beta value & Significance level & Adjusted R2 \\
\hline $\begin{array}{l}\text { Performance management } \\
\text { factor }\end{array}$ &, 538 &, 000 &, 276 \\
\hline Mean maturity score &, 526 &, 000 &, 263 \\
\hline $\begin{array}{l}\text { Assortment management } \\
\text { factor }\end{array}$ &, 463 &, 000 &, 200 \\
\hline Stock management factor 2 &, 445 &, 001 &, 184 \\
\hline Vendor management factor 1 &, 421 &, 001 &, 162 \\
\hline Execution factor 1 &, 371 &, 005 &, 122 \\
\hline Strategy factor &, 345 &, 009 &, 103 \\
\hline Data management factor &, 295 &, 026 &, 071 \\
\hline
\end{tabular}

Table 3. Regression analysis

performance on actual performance outcomes (Ittner 2008), it is in fact the most important process in our grid that a supply chain manager should pay attention to. This may also explain the importance that is typically adhered to measuring performance by many academics (Akyuz \& Erkan 2009; Gunasekaran \& Kobu 2007) as well as supply chain practitioners (Chae 2009). Our research furthermore suggests that it is not so much the just the definition of performance metrics that needs attention but the complete process from definition to using and managing with performance metrics in day-to-day activities. Key aspects addressed in the maturity grid for the factor Performance Management pertain to not only definition of indicators but also the extent to which they are communicated and the extent to which they are explicitly part of an improvement process. It is particularly the implementation and use of performance indicators that has a large impact on performance outcomes, and this requires more academic research (Bourne et al. 2000).

Linear regression furthermore suggested that maturity in product assortment management plays a key role in managing and improving supply chain performance. Van Ryzin and Mahajan (1999) already indicated that assortment size influences performance; our research extends this finding by showing that also the maturity of the process of managing product assortments is key to supply chain performance. In the realm of Efficient Consumer Response (ECR), managing assortments has received significant attention, though that is mainly with the objective to optimise productivity of inventories and store-space at the consumer interface (Svensson 2002). Our detailed findings suggest that the more mature process an organisation has for managing assortments, by means of closely managing and monitoring product introductions and a joint assortment planning with partners, the higher the expected performance will be. This supports the statement of Homlström et al. (2002) who argue that ECR contains a missing link as each entity in the chain still plans assortments independently. All in all, in the supply chain realm, research on assortment management so far has mainly focused on issues related to variety of the assortment, such as depth and width of product ranges required. However, given its effect on supply chain performance, research is particularly needed on the process of managing the assortment from a supply chain perspective. Holmström (1997) concluded that assortment management is an overlooked area of supply chain management. We contend that this gap has not yet been filled sufficiently.

Stock management factor 3 (organisation), vendor management factor 1 (vendor analysis) and execution factor 1 (up to date information) have about an equally strong relation with order fill rate. Stock management factor 3 consists of clear and detailed specifications of responsibilities over inventory and clear division of tasks across sites about who is doing 
what positively influence performance. This shows that the organisational aspects of managing inventory need to be carefully considered. Unclear organisational aspects such as responsibilities, managerial commitment and conflicting policies may be a significant barrier to effective supply chain management (Fawcett et al. 2008).

In managing vendors, particularly measuring vendor performance and understanding and managing risks on the supply side impacts performance. Fawcett et al. (2008) found that a lack of willingness to manage risks jointly was perceived as an obstacle to effective supply chain management; managing these risks is therefore critical in achieving high performance levels. This also suggests that managing performance is particularly relevant across partners, not just within a company. This confirms Lockamy and McCormack (2004b) who found a positive impact of collaboration, measurement and integration across partners on supply chain performance.

The fact that the process of developing and reviewing a strategy is related to order fill rate confirms and extends earlier research that strategy is key to business performance (Bendoly et al. 2007); however we only find a weak relation. Data management is only weakly related to performance, supporting the finding of Lockamy and McCormack (2004b: 1210) that "...information technology solutions are only part of the answer to improved supply chain performance".

Last, we have calculated an overall mean score by averaging the maturity scores on all practices. It turns out that the overall mean maturity score has a nearly equally strong relation with performance as the factor Performance Management. Estimated changes in average maturity score on our instrument may thus be a guide for assessing effects on future supply chain performance.

\section{Conclusions and implications}

Self-assessment of supply chain process maturity is a type of benchmarking that has benefited little from academic contributions (Akyuz \& Erkan 2009). In this chapter, we have described the development and application of a self-assessment supply chain maturity grid. We have used the data from 57 companies that filled out the assessment grid to understand how supply chain maturity assessment can contribute to the improvement of companies, which is ultimately the goal of a benchmarking exercise.

The data used from a maturity model such as discussed in this chapter enables companies to define target maturity levels and compare target to actual maturity levels. As such, a maturity model is a powerful tool to support strategies of a company, particularly because target and actual maturity in different processes can be compared easily with a spider diagram. Fig. 2 provides an example of such a spider diagram.

Managerial implications of our study are twofold. First, our results suggest that performance management is key in achieving high performance levels, particularly across organisational boundaries. Performance management should be the first and foremost process a supply chain manager pays attention to if high levels of supply chain performance are strived for. Aspects that managers should focus on are an introduction of a Plan-DoCheck-Act cycle to guide process improvement, communication of performance metrics to stakeholders, ensuring a balance of metrics, a focus on learning from one another and in particular a cross-organisational view on measuring performance.

Secondly, our analysis shows the importance of assortment management across companies. The extent to which product introductions are managed and monitored and the degree of 


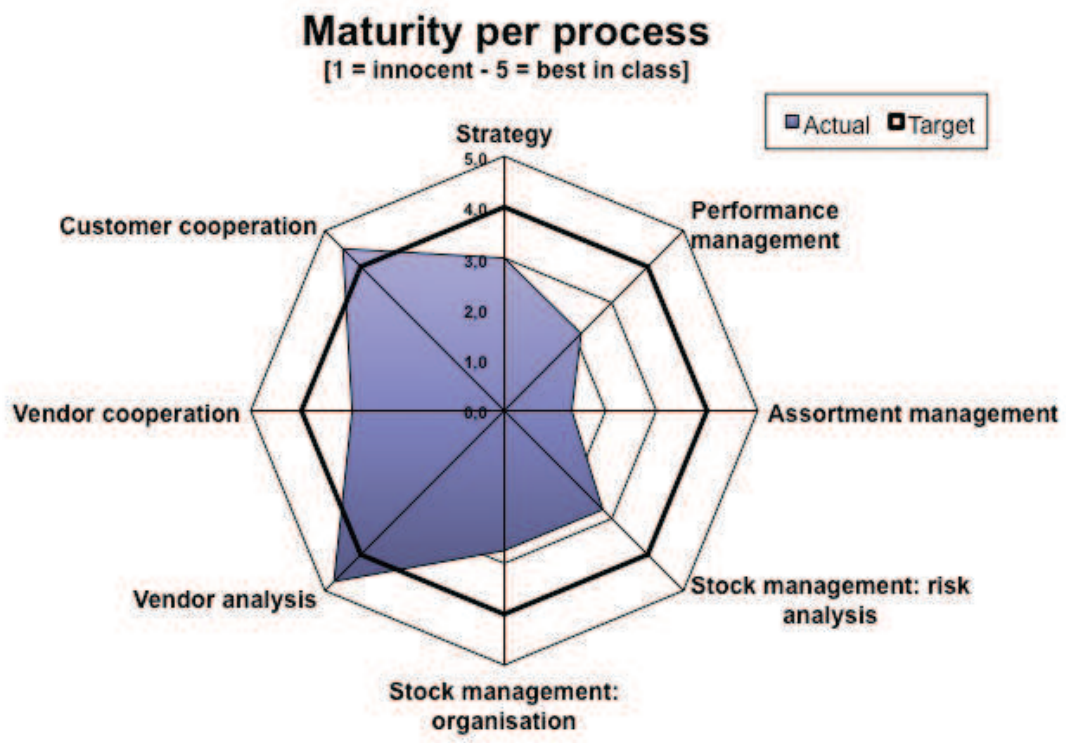

Fig. 2. Sample maturity spider diagram

joint planning together with partners in the supply chain are practices that contribute significantly to achieving high performance levels. It is not uncommon in business practice that the number of stock keeping units grows quite rapidly based on desires of sales departments to introduce new product versions. Our results suggest that this should be done in close cooperation with partners to have the right product versions available. They furthermore suggest that the process be managed closely and that there be quick feedback mechanisms in place to judge the success of a new product quickly and take decisions accordingly.

The theoretical implications of our results are the following. First, literature asserts that it is not so much the definition of performance metrics that requires attention but in particular the process of implementation (Bourne et al. 2000). Our analysis confirms that maturity in measuring and managing performance in a company plays a key role in achieving high levels of supply chain performance. Practices that support this, such as the implementation of a PDCA cycle and communication about performance metrics turn out to support reaching high performance levels. As such, our results provide further evidence that particularly the human elements such as communication are critical in successfully developing and implementing a performance measurement system.

Secondly, our research shows the importance of maintaining a cross-company perspective in managing processes, particularly in managing performance and managing assortments. Previous research has shown that companies that are integrated with partners in the supply chain perform better (Frohlich \& Westbrook 2001; Singh \& Power 2009); our research provides further guidance by identifying relevant practices for such integration.

Thirdly, our results show the importance of managing assortments, an area that has received ample marketing attention but relatively scant attention in the context of supply chain management. The debate in the supply chain domain so far has mainly focused on depth and width of an assortment, not on the process of managing assortments as such. 
Our research findings are limited by the size of the sample and the section of industry we have focused on. A larger sample may be useful to expand findings. We furthermore focus on companies delivering a significant variety from stock, with a large representation of wholesalers in our sample. The need for good assortment management in such companies may be not surprising at first hand due to typical assortment sizes in these companies. However, we did not find any effect of assortments size on performance in our sample. A replication of this research in other industry segments may provide additional directions.

Discussions during the summer course event where companies filled out the grid revealed that they found it a very useful exercise to go through such a grid. Companies argued that it evoked discussion and can provide concrete guidance to improvement in supply chain processes. In the weeks and months after this summer course, we received many requests from summer course participants to make the maturity grid available in a digital format. Upon further inquiry, it turned out that many had started to use the maturity grid in their companies as an instrument to develop a growth path for their supply chain, which is exactly what the self-assessment grid has been intended for. Several of these companies used the grid to develop a supply chain strategy together with selected suppliers and customers. As such, the grid was a useful facilitating tool for goal setting with supply chain partners. Though we have not performed a formal evaluation among course participants, we believe the above is a good indication for the usefulness of a self-assessment grid in practice.

There are several interesting avenues for future research besides the application of the grid on a larger and wider sample. First of all, a longitudinal study on a company applying the grid and using the grid for defining an improvement strategy would show if and how the use of a maturity model can induce performance improvement. Secondly, research on process maturity across partners in a supply chain would enable the detection of which practices truly matter from a cross-company perspective. This could be done by for example following a product from raw materials to finish product and investigate triads of companies that are supplier/customer of each other in that supply chain and that are involved in making and distributing that product.

Albeit we have not been able to obtain data from a large sample with a variety of industries, our research shows that there is a need to further research self-assessment supply chain maturity grids: both academia and practice are in need of validated maturity assessment instruments.

\section{References}

Akyuz, G.A. and Erkan, T.E. [2009], 'Supply chain performance measurement: a literature review', International Journal of Production Research, First published on: 25 August 2009 (iFirst).

Bendoly, E., Rosenzweig, E.D., and Stratman, J.K. [2007], 'Performance Metric Portfolios: A Framework and Empirical Analysis', Production and Operations Management, Vol. 16, No. 2, pp. 257-76.

Bourne, M., Neely, A., Platts, K., and Mills, J. [2002], 'The success and failure of performance measurement initiatives', International Journal of Operations $\mathcal{E}$ Production Management, Vol. 22, No. 11, pp. 1288-310.

Bourne, M., Mills, J., Wilcox, M., Neely, A., and Platts, K. [2000], 'Designing, implementing and updating performance measurement systems', International Journal of Operations and Production Management, Vol. 20, No. 7, pp. 754-71. 
Braam, G.J.M. and Nijssen, E.J. [2004], 'Performance effects of using the Balanced Scorecard: a note on the Dutch experience', Long Range Planning, Vol. 37, No. 4, pp. 335-49.

Camp, R.C. [1989], Benchmarking - The Search for Industry Best Practices that lead to Superior Performance (Milwaukee: ASQ Quality Press).

Chae, B.K. [2009], 'Developing key performance indicators for supply chain: an industry perspective', Supply Chain Management: An International Journal, Vol. 14, No. 6, pp. 422-28.

Crosby, P.B. [1979], Quality is free: The art of making quality certain (New York: New American Library New York).

Davies, A.J. and Kochhar, A.K. [2002], 'Manufacturing best practice and performance studies: a critique', International Journal of Operations \& Production Management, Vol. 22, No. 3, pp. 289-305.

Eisenhardt, K.M. [1989], 'Building Theory from Case Study Research', Academy of Management Review, Vol. 14, No. 4, pp. 532-50.

Fawcett, S.E., Magnan, G.M., and McCarter, M.W. [2008], 'Benefits, barriers, and bridges to effective supply chain management', Supply Chain Management: An International Journal, Vol. 13, No. 1, pp. 35-48.

Ferber, R. [1977], 'Research by convenience', Journal of Consumer Research, Vol. 4, No. 1, pp. 57-58.

Forza, C. [2002], 'Survey research in operations management: a process-based perspective', International Journal of Operations \& Production Management, Vol. 22, No. 2, pp. 15294.

Fraser, P., Moultrie, J., and Gregory, M. (2002). The use of maturity models/grids as a tool in assessing product development capability. IEEE International Engineering Management Conference, Cambridge, IEMC.

Frohlich, M.T. and Westbrook, R. [2001], 'Arcs of integration: an international study of supply chain strategies', Journal of Operations Management, Vol. 19, No. 2, pp. 185200.

Green Jr, K.W., Whitten, D., and Inman, R.A. [2008], 'The impact of logistics performance on organizational performance in a supply chain context', Supply Chain Management: An International Journal, Vol. 13, No. 4, pp. 217-27.

Gunasekaran, A. and Kobu, B. [2007], 'Performance measures and metrics in logistics and supply chain management: a review of recent literature (1995-2004) for research and applications', International Journal of Production Research, Vol. 45, No. 12, pp. 2819-40.

Hair, J.F., Black, W.C., Babin, B.J., Anderson, R.E., and Tatham, R.L. [2006], Multivariate data analysis (6 edn.; Upper Saddle River, NJ: Pearson Prentice Hall).

Hammer, M. [1990], 'Reengineering work: don't automate, obliterate', Harvard Business Review, Vol. 68, No. 4, pp. 104-12.

Harter, D.E., Krishnan, M.S., and Slaughter, S.A. [2000], 'Effects of process maturity on quality, cycle time, and effort in software product development', Management Science, Vol., pp. 451-66.

Hendricks, K.B. and Singhal, V.R. [2008], 'Demand-supply mismatch and stock market reaction: Evidence from excess inventory announcements', (Atlanta: Working paper, Georgia Institute of Technology). 
Holmstrom, J., Framling, K., Kaipia, R., and Saranen, J. [2002], 'Collaborative planning forecasting and replenishment: new solutions needed for mass collaboration', Supply Chain Management: An International Journal, Vol. 7, No. 3, pp. 136-45.

Holmström, J. [1997], 'Product range management: a case study of supply chain operations in the European grocery industry', Supply Chain Management: An International Journal, Vol. 2, No. 3, pp. 107-15.

Ibbs, C.W. and Kwak, Y.H. [2000], 'Assessing project management maturity', Project Management Journal, Vol. 31, No. 1, pp. 32-43.

Ittner, C.D. [2008], 'Does measuring intangibles for management purposes improve performance? A review of the evidence', Accounting and Business Research, Vol. 38, No. 3, pp. 261-72.

Kaiser, H.F. [1974], 'An index of factorial simplicity', Psychometrika, Vol. 39, No. 1, pp. 31-36.

Kim, S.W. [2006], 'Effects of supply chain management practices, integration and competition capability on performance', Supply Chain Management: An International Journal, Vol. 11, No. 3, pp. 241-48.

Kwak, Y.H. and Ibbs, C.W. [2002], 'Project Management Process Maturity (PM) Model', Journal of Management in Engineering, Vol. 18, pp. 150-5.

Lambert, D.M. and Cooper, M.C. [2000], 'Issues in supply chain management', Industrial Marketing Management, Vol. 29, No. 1, pp. 65-83.

Laugen, B.T., Acur, N., Boer, H., and Frick, J. [2005], 'Best manufacturing practices', International Journal of Operations \& Production Management, Vol. 25, No. 2, pp. 13148 .

Lee, H.L. and Billington, C. [1992], 'Managing supply chain inventory: pitfalls and opportunities', Sloan Management Review, Vol. 33, No. 3, pp. 65-73.

Lockamy III, A. and McCormack, K. [2004a], 'The development of a supply chain management process maturity model using the concepts of business process orientation', Supply Chain Management: An International Journal, Vol. 9, No. 4, pp. 272-78.

Lockamy III, A. and McCormack, K. [2004b], 'Linking SCOR planning practices to supply chain performance; an exploratory study', International Journal of Operations and Production Management, Vol. 24, No. 12, pp. 1192-218.

Lockamy III, A., Childerhouse, P., Disney, S.M., and Towill, D.R. [2008], 'The impact of process maturity and uncertainty on supply chain performance: an empirical study', International Journal of Manufacturing Technology and Management, Vol. 15, No. 1, pp. 12-27.

McCormack, K., Ladeira, M.B., and de Oliveira, M.P.V. [2008], 'Supply chain maturity and performance in Brazil', Supply Chain Management: An International Journal, Vol. 13, No. 4, pp. 272-82.

Melnyk, S.A., Stewart, D.M., and Swink, M. [2004], 'Metrics and performance measurement in operations management: dealing with the metrics maze', Journal of Operations Management, Vol. 22, No. 3, pp. 209.

Moultrie, J., Clarkson, P.J., and Probert, D. [2006], 'A tool to evaluate design performance in SMEs', International Journal of Productivity and Performance Management, Vol. 55, No. 3/4, pp. 184.

Neely, A., Mills, J., Platts, K., Richards, H., Gregory, M., Bourne, M., and Kennerley, M. [2000], 'Performance measurement system design: developing and testing a 
process-based approach', International Journal of Operations and Production Management, Vol. 20, No. 9/10, pp. 1119-145.

Paulk, M.C., Curtis, B., Chrissis, M.B., and Weber, C.V. [1993], 'Capability maturity model, version 1.1', (10), pp. 64.

Plomp, M. and Batenburg, M.R.S. [2010], 'Measuring chain digitisation maturity: An assessment of Dutch retail branches', Supply Chain Management: An International Journal, Vol. 15.

Ramdas, K. and Spekman, R.E. [2000], 'Chain or shackles: understanding what drives supply-chain performance', Interfaces, Vol., pp. 3-21.

Sharman, G. [2003], 'Building the successful multinational distributor', Supply Chain Forum: An International Journal, Vol. 4, No. 1, pp. 28-34.

Shin, H., Collier, D.A., and Wilson, D.D. [2000], 'Supply management orientation and supplier/buyer performance', Journal of Operations Management, Vol. 18, No. 3, pp. 317-33.

Singh, P.J. and Power, D. [2009], 'The nature and effectiveness of collaboration between firms, their customers and suppliers: a supply chain perspective', Supply Chain Management: An International Journal, Vol. 14, No. 3, pp. 189-200.

Spekman, R.E., Kamauff, J.W., and Myhr, N. [1998], 'An Empirical Investigation into Supply Chain Management: a Perspective on Partnerships', Supply Chain Management: An International Journal, Vol. 3, No. 2, pp. 53-67.

Stewart, G. [1997], 'Supply-chain operations reference model (SCOR): the first cross-industry framework for integrated supply-chain management', Logistics Information Management, Vol. 10, pp. 62-67.

Svensson, G. [2002], 'A firm's driving force to implement and incorporate a business philosophy into its current business activities: the case of ECR', European Business Review, Vol. 14, No. 1, pp. 20-30.

Swink, M., Narasimhan, R., and Kim, S.W. [2005], 'Manufacturing practices and strategy integration: effects on cost efficiency, flexibility, and market-based performance', Decision Sciences, Vol. 36, No. 3, pp. 427-57.

Tummala, V.M.R., Phillips, C.L.M., and Johnson, M. [2006], 'Assessing supply chain management success factors: a case study', Supply Chain Management: An International Journal, Vol. 11, No. 2, pp. 179-92.

Ungan, M. [2005], 'Management support for the adoption of manufacturing best practices: key factors', International Journal of Production Research, Vol. 43, No. 18, pp. 3803-20.

Van Dijk, E., de Leeuw, S., and Durlinger, P. [2007], Voorraadbeheer in Perspectief; zeven invalshoeken van het vak (in Dutch) (Deventer: Slimstock B.V.).

Van Landeghem, R. and Persoons, K. [2001], 'Benchmarking of logistical operations based on a causal model', International Journal of Operations and Production Management, Vol. 21, No. 1/2, pp. 254-66.

van Ryzin, G. and Mahajan, S. [1999], 'On the relationship between inventory costs and variety benefits in retail assortments', Management Science, Vol. 45, No. 11, pp. 1496509.

Voss, C.A., Chiesa, V., and Coughlan, P. [1994], 'Developing and testing benchmarking and self-assessment frameworks in manufacturing', International Journal of Operations and Production Management, Vol. 14, pp. 83-101. 
Whybark, D.C. and Vastag, G. (eds.) [1993], Global manufacturing practices - a world-wide survey of practice in production planning and control (Amsterdam: Elsevier).

Zirger, B.J. and Maidique, M.A. [1990], 'A Model of New Product Development: An Empirical Test', Management Science, Vol. 36, No. 7, pp. 867-83. 


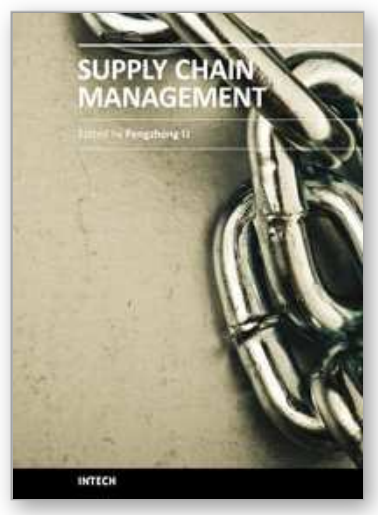

\section{Supply Chain Management}

Edited by Dr. pengzhong Li

ISBN 978-953-307-184-8

Hard cover, 590 pages

Publisher InTech

Published online 26, April, 2011

Published in print edition April, 2011

The purpose of supply chain management is to make production system manage production process, improve customer satisfaction and reduce total work cost. With indubitable significance, supply chain management attracts extensive attention from businesses and academic scholars. Many important research findings and results had been achieved. Research work of supply chain management involves all activities and processes including planning, coordination, operation, control and optimization of the whole supply chain system. This book presents a collection of recent contributions of new methods and innovative ideas from the worldwide researchers. It is aimed at providing a helpful reference of new ideas, original results and practical experiences regarding this highly up-to-date field for researchers, scientists, engineers and students interested in supply chain management.

\section{How to reference}

In order to correctly reference this scholarly work, feel free to copy and paste the following:

Sander de Leeuw (2011). Supply Chain Process Benchmarking Using a Self-Assessment Maturity Grid, Supply Chain Management, Dr. pengzhong Li (Ed.), ISBN: 978-953-307-184-8, InTech, Available from: http://www.intechopen.com/books/supply-chain-management/supply-chain-process-benchmarking-using-aself-assessment-maturity-grid

\section{INTECH}

open science | open minds

\author{
InTech Europe \\ University Campus STeP Ri \\ Slavka Krautzeka 83/A \\ 51000 Rijeka, Croatia \\ Phone: +385 (51) 770447 \\ Fax: +385 (51) 686166 \\ www.intechopen.com
}

\author{
InTech China \\ Unit 405, Office Block, Hotel Equatorial Shanghai \\ No.65, Yan An Road (West), Shanghai, 200040, China \\ 中国上海市延安西路65号上海国际贵都大饭店办公楼 405 单元 \\ Phone: +86-21-62489820 \\ Fax: +86-21-62489821
}


(C) 2011 The Author(s). Licensee IntechOpen. This chapter is distributed under the terms of the Creative Commons Attribution-NonCommercialShareAlike-3.0 License, which permits use, distribution and reproduction for non-commercial purposes, provided the original is properly cited and derivative works building on this content are distributed under the same license. 